\title{
Implementation of Sufism Approach Character Education (Case Study of Jagad 'Alimussirry Islamic Boarding School)
}

\author{
Ulil Anwar', Asmaul Lutfauziah'2, Djoko Hartono ${ }^{3}$ \\ ${ }^{1}$ Islamic Boarding School of Jagad Alimussirry Surabaya, Indonesia \\ ${ }^{2}$ UNUSA, Indonesia \\ ${ }^{3}$ IAI Al-Khoziny Sidoarjo, Indonesia
}

\begin{abstract}
.
This study aims to: (1) find out the application of Sufism-based character education in Jagad Alimussirry Islamic Boarding School, (2) find out how to implement Sufism education in Jagad Alimussirry Islamic Boarding School, and (3) know the importance of Sufism education in shaping the character of students in Jagad Alimussirry Islamic Boarding School. This type of research is qualitative research with a case study approach. The results showed: (1) Character education with a Sufism approach has been implemented at Jagad Alimussirry Islamic Boarding School, (2) Implementation of character education is adjusted to the tirakatan curriculum and behaviour at Jagad Alimussirry Islamic Boarding School, and (3) The importance of Sufism education in character building to educate students to become Muslim scholars lover/guardian of Allah and the character that is expected to be contextualized in life in society.
\end{abstract}

Keywords: character education, Sufism education, Jagad Alimussirry Islamic Boarding School

\section{INTRODUCTION}

Education is a process of internalizing culture into a person and society to make people and society civilized. Education is a conscious and planned effort to create a learning atmosphere and learning process so that students actively develop their potential to have religious-spiritual strength, self-control, personality, intelligence, morals and skills needed by themselves, society, nation and state, as well as helping children students in preparing essential needs to deal with change.

It is stated in Article I of Law Number 20 of 2003 concerning the National Education System that the purpose of National Education is to develop the potential of students to have intelligence, personality and noble character. The above objectives illustrate that education does not only form intelligent people but also has a strong personality or character and has a noble character who breathes the noble values of the nation and religion. Character is an important aspect for improving the quality of community resources because the quality of the nation's character determines the progress of a nation.

Corresponding author: Ulil Anwar. Email: ulil.17040284033@mhs.unesa.ac.id

(C) 2021 Journal Intellectual Sufism Research (JISR)

Doi: https://doi.org/10.52032/jisr.v4i1.109 
This is quite relevant when juxtaposed with the Minister of Education and Culture Regulation number 20 of 2018 which contains Strengthening Character Education in which there are eighteen character values which include religion, honest, tolerance, discipline, hard work, creativity, independence, democratic, curiosity, national spirit, love for the homeland, respect for achievement, communicative, love peace, love to read, care for the environment, care for social, and responsibility.

In the life of Indonesian society today, there is a character crisis. The character crisis that afflicts the young generation of Indonesia indirectly affects their personality and daily behaviour. Education is a medium of improvement as well as the formation of the character of the Indonesian people because education is still an effective means to educate the nation's life, both in terms of knowledge and mental attitude. The application of character education in Indonesia should not only focus on the formation of attitudes or behaviour but must also strengthen religious values based on spirituality and Sufism.

Sufism-based education is an effort to develop, encourage and invite people to return to human nature who obey God. Human nature to obey God can be through a vertical amaliah approach to God such as obedience in worship or horizontally establishing relationships with fellow humans and God's creatures. To get closer to Allah can be through educational institutions engaged in Sufism. One of the institutions that use the Sufism approach in its teaching and learning activities is the Jagad 'Alimussirry Islamic Boarding School.

The Jagad 'Alimussirry Islamic Boarding School is a boarding school in the form of a combination of the salaf and modern Islamic boarding schools based on Nahdliyin with the majority of students coming from among the students. This Islamic boarding school implements non-formal education for undergraduate and postgraduate programs in Islamic studies with a Sufism approach. The reason that underlies the establishment of an educational institution in the form of Jagad 'Alimussirry Islamic Boarding School which combines general education, Sufism and character is that it is expected to be a forum for educating, fostering, maintaining and improving the faith and good morals of the younger generation.

Based on the importance of character education as stated in the Regulation of the Minister of Education and Culture regarding strengthening character education for the Indonesian people as well as the importance of spirituality and Sufism as a medium for forming the character of society faced with the problems faced now, the purpose of writing this research is to determine the application of Sufism-based character education, how to implement education. with the Sufism approach and the importance of Sufism education in shaping the character of students at Jagad Alimussirry Islamic Boarding School.).

\section{METHOD}

The type of research used in this research is case study research. Case study research is a method of researching and investigating a contemporary phenomenon. The subject of the research was carried out by identifying someone who had the criteria as the main resource person, in this 
study the President Director of Jagad 'Alimussirry Islamic Boarding School and supporting informants, namely Jagad 'Alimussirry Islamic Boarding School students. The instrument used in this research is the human instrument. Researchers as human instruments collect data from observations, interviews, and documentation. Data collection methods in this study used several methods to obtain complete data, namely observation, interviews and documentation. The data obtained were then analyzed descriptively qualitatively by collecting facts and describing them.

\section{RESULT AND DISCUSSION}

\section{A. Sufism-Based Character Education at Jagad Alimussirry Islamic Boarding School}

In Jagad 'Alimussirry Islamic Boarding School, it has the characteristics of Sufism education, so the characters that are built are Sufism-based characters. When science is practised, it is called Sufism education or Sufi education. Sufis or salik are people who take the path of Sufism which of course will have an impact on the Sufi character. Sufism-based character education is educating the Sufism character of students with tirakat behaviour. The hope is that this behaviour will change the mindset and behaviour of the students themselves. Because the practice of Sufism at Jagad 'Alimussirry Islamic Boarding School it empowers the potential of the mind, the potential of the heart, and the potential of the physical and spiritual.

Sufism-based character education by the vision, mission and goals Jagad 'Alimussirry Islamic Boarding School, namely: his vision is to become the centre of education for scholars, scholars, lovers/Wali Allah SWT; and the mission is 1) To provide the best integral Islamic education to the students. 2) Delivering the students/women to success in the world and the hereafter, which is blessed by Allah SWT. 3) Print the lovers/guardians of Allah SWT by their respective professions and competencies. Meanwhile, among the objectives are:

1. Realizing students who love and are loved by Allah.

2. Realizing students/women to become caliphs/world leaders who can realize goodness, honesty, justice, and the welfare of human beings who have good character.

3. Realizing students who think and act and behave that respect plurality and universality in life and social life, as a nation, as a state in the world arena.

4. Realizing disciplined students and istiqomah in worship with full sincerity in all its aspects.

\section{B. Implementation of Education with a Sufism Approach}

The implementation of character education in Indonesia varies according to the basic curriculum and the curriculum of educational institutions. Because Jagad 'Alimussirry Islamic Boarding School has a curriculum that combines the curriculum in public universities, Islamic universities and modern Sufism, so the application of character education which refers to the Regulation of the Minister of Education and Culture of the Republic of Indonesia Number 20 of 2018 concerning Character Strengthening can be combined with Sufism education according to the curriculum in Indonesia.

Character-based on the Regulation of the Minister of Education and Culture of the Republic of Indonesia Number 20 of 2018 concerning Character Strengthening and Sufism education by the 
curriculum in Jagad 'Alimussirry Islamic Boarding School character and indicators can be formulated as follows:

1. Religious, istiqomah pray because they feel as obedient and needy servants of Allah, recite and read the Qur'an with sincerity and hope for Allah's pleasure, perform the obligatory prayers 5 times in congregation in strengthening the banner of Islam, and maintain the purity of heart, mind, words and actions by imitating the clear and clear spring water symbol.

2. Honest, trustworthy in the social environment as a person who is honest and trustworthy, consistent between thoughts, words and actions and does not conflict with behaviour in society, recognizes and understands personal strengths and weaknesses, and is open and friendly to others in social interactions in society.

3. Tolerance, mutual respect for various opinions because they understand that everyone has different thoughts, be humble and reduce each other's ego in discussing fellow students, maintaining the calm and peace of the cottage by understanding the clear and calm spring water and discussing the news with each other. accepted during tirakatan because each salik has different news.

4. Discipline, obeying the rules of the lodge as students who are obedient to the murabbi, students carrying out obligatory prayers on time with pleasure and love for God's commands, attending science majlis (recitation) according to schedule as a form of implementation of sami'na wa 'atho'na, and carry out the remembrance and wirid that have been obtained after the prayer.

5. Hard work, carrying out the duties and mandates given by the murabbi as well as possible, being serious in learning and doing charity with the intention of Allah and not because of going along with it, never giving up in carrying out tirakatan because they realize that each student has a different process, and earnestly in carrying out the tirakatan cottage in the hope of being loved by Allah.

6. Creative, looking for contextual meaning and meaning from each given tirakatan task, looking for alternative solutions to any problems encountered, having new ideas about understanding and carrying out tirakatan duties, and being innovative individuals in working in their respective lives.

7. Independent, planning and carrying out structured learning activities, managing study time well because he understands God's verses about time, like tasks that can train an independent attitude, and has high ideals and hopes, both in the world and the hereafter.

8. Democratic, asking the murabbi when they feel they do not understand the meaning of the news received during the tirakat, willing to accept suggestions and criticism from the murabbi's explanation of the news received during the tirakat, providing an objective assessment of various things that happen in the cottage to make the cottage better and developing, and take responsibility for yourself because you understand that every deed and deed in this world will be rewarded in the hereafter. 
9. Curiosity, doing something new in learning so that the sense of seeking knowledge is higher, asking experts because they understand that there is an order to ask knowledge from experts, the spirit of continuing tirakatan to the next level with enthusiasm and a sense of gratitude to Allah, as well as interpreting and contemplating every news and signal during tirakatan because science is titen.

10. The spirit of nationality, singing the national obligatory anthem when there are big activities at Jagad Alimussirry Islamic Boarding School, implementing the nationalist spirit in social life because he understands that the Prophet also loves his homeland, upholds the spirit of student unity because when they are more united, Islam will be stronger, and advance the nation according to their duties and responsibilities. their respective professions.

11. Love the homeland, love the culture and traditions of tahlilan, manaqiban, sholawatan, revive culture in social life as a form of respect for ancestral culture, maintain the alma mater and PPJA's good name, and mahabbah to murabbi because he is a spiritual and physical guidance teacher.

12. Appreciating achievements, improving and developing interests and talents according to their respective expertise, happy to see fellow students who achieve achievements as a form of purification of the heart, mutual support for fellow students to achieve achievements in the form of cooperation in goodness, and appreciate the level of tirakatan that is carried out and the spirit of increasing levels next step.

13. Communicative, polite and maintain oral in speaking because every utterance is a prayer, have a sense of humour and is not rigid in speaking so that it adds a sense of familiarity, is clear and straightforward in speaking so as not to waste time, and practices communicating with all of God's creatures, both living and non-living.

14. Love of peace, maintain the peace of the atmosphere in the cottage so that there is a sense of solemnity in activities, including worship, resolving disputes between students because they understand the commandment about reconciling between two believers, smiling and greeting students as an effort to form alms, as well as loving and exploring the wisdom of tirakatan because every penance teaches about peace of mind.

15. Likes to read, always reads books and various reading sources every day based on the Iqra command in the Qur'an, always observes events in the natural surroundings and meditates on nature, responds quickly to cues in every situation, and reads and understands the feelings and behaviour of fellow students so that titen to various things.

16. Caring for the environment, always maintaining the security of the cottage such as picket guarding the cottage environment every Koran, always maintaining the cleanliness of the room as a form of personal responsibility regarding the sanctity and cleanliness of the place, tidying up messy items because they understand that tidying things up is one of etiquette and manners, and observing and understand the surrounding natural conditions to train taste sensitivity. 
17. Social care, helping each other with assignments given between students because by working together, tasks will be more easily completed, greeting each other when meeting as a form of strengthening relationships between students, supporting each other in social activities such as Amil zakat infaq and shadaqah institution of Jagad 'Alimussirry, and inviting fellow students who have not been converted to participate as a form of effort to get closer to Allah.

18. Responsibilities, students carry out picket according to schedule because they understand their responsibilities, do the tasks given by the murabbi with pleasure and full responsibility, know and carry out activities that are obligations at the cottage, and pay infaq syahriah according to the schedule intended to give alms to the cottage for the development of the cottage and Islamic symbols.

\section{The Importance of Sufism Education in Character Building}

Sufism-based character education in Indonesia Jagad 'Alimussirry Islamic Boarding School has an important meaning in educating students to become Muslim scholars who are lovers/guardians of Allah. One of them is educating humans who have good relationships with fellow humans and God. Character education with a Sufism approach is important because it aims to shape a human character that is oriented towards the world and the hereafter. This orientation teaches about good relationships with fellow human beings and God with good and appropriate attitudes and characters. Through tirakatan and behaviour that is in Jagad 'Alimussirry Islamic Boarding School is expected to be a way for students who take the path of Sufism to be closer to Allah. During the path of Sufism with the aforementioned characters, there are supporting and inhibiting factors. The formation of character is influenced by two internal factors and external factors outside of him. Internal factors that come from within him such as sincerity and thoroughness will affect the formation of character. If you follow tirakatan, you only follow along and don't explore it, you will not be able to form character. External factors come from outside, can be influenced by the teacher, the circle of friends, and the habits that exist in the cottage.

To overcome the inhibiting factors, the solution is to be aware. Realizing that he wants to change for the better somehow. When you have realized then two things need to be done, namely asking God and introspection. Asking Allah to show the right thing and be given the power to carry it out and show the wrong thing and be given the power to stay away from it. For introspection, it is necessary to reflect and correct oneself about what has been done and done during his life.

\section{CONCLUSION}

Based on the results of research on the implementation of character education with a Sufism approach, a case study of the Jagad 'Alimussirry Islamic Boarding School can be concluded, including: 
1. Character education with a Sufism approach has been carried out by the regulation of the Minister of Education and Culture of the Republic of Indonesia Number 20 of 2018 concerning strengthening character education and curriculum in Indonesia.

2. The implementation of character education in Minister of Education and Culture Regulation Number 20 of 2018 concerning strengthening character education is adjusted to the tirakatan curriculum and behaviour in Jagad Alimussirry Islamic Boarding School such as wirid and riyadhoh behaviour. All forms of wiridan and riyadhoh contain their character and need to be contemplated by each student who carries out the practice of tirakat.

3. Sufism-based character education in Indonesia Jagad 'Alimussirry Islamic Boarding School has an important meaning in educating students to become Muslim scholars who are lovers/guardians of Allah. Characters are expected to be contextualized in life in society. There are supporting and inhibiting factors in forming Sufism-based characters, namely internal ones that come from students and external ones that come from outside. The solution in overcoming the inhibiting factors both internal and external is to be aware of yourself and not to lie to yourself.

\section{REFERENCES}

Ali, M. (2019). Pendidikan Karakter Berwawasan Tasawuf. Suhuf, 1-12.

Damis, R. (2014). Nilai-Nilai Pendidikan Karakter pada Ajaran Cinta dalam Tasawuf. Al-Ulum, $127-152$.

Hartono, D. (2018). Amaliyah Thariqat Jagad 'Alimussirry: Wasilah Meraih Maqom Ma'rifatullah. Surabaya: Jagad 'Alimussirry.

Hartono, D., \& Damayanti, T. (2016). Mengembangkan Spiritual Pendidikan: Solusi Mewujudkan Masyarakat Meraih Kemenangan di Era Pasar Bebas. Surabaya: Jagad 'Alimussirry.

Husen, A. (2014). Pendidikan Karakter Berbasis Spiritualisme Islam (Tasawuf). Jurnal Studi AlQuran, 1-19.

Ilahi, M. T. (2014). Gagalnya Pendidikan Karakter: Analisis dan Solusi Pengendalian Karakter Emas Anak Didik. Yogyakarta: Ar-Ruzz Media.

Nahrawi, I., \& Hartono, D. (2017). Memberdayakan Pendidikan Spiritual Pencak Silat: Solusi Mewujudkan Kedamaian dalam Hidup Bermasyarakat. Surabaya: Jagad 'Alimussirry.

Rofi, S., Prasetiya, B., \& Setiawan, B. A. (2019). Pendidikan Karakter dengan Pendekatan 
Ulil,A. , Azmaul,L. \& Djoko,H., 2021

Tasawuf Modern Hamka dan Transformatif Kontemporer. Intiqad: Jurnal Agama dan Pendidikan Islam, 396-414.

Santoso, T. R., \& Cahrolis, L. (2018). Critical Analisys: Konsep Pendidikan Karakter dalam Perspektif Tasawuf. Latifah, 14-29.

Sugiyono. (2015). Metode Penelitian Pendidikan: Pendekatan Kuantitatif, Kualitatif, dan R\&D. Bandung: Alfabeta. 